\title{
Causality and Cointegration between Economic Growth and Energy Consumption: Econometric Evidence from Jordan
}

\author{
Mohammed Issa Shahateet ${ }^{1}$, Khalid Ali Al-Majali ${ }^{2} \&$ Fedel Al-Hahabashneh ${ }^{2}$ \\ ${ }^{1}$ King Talal Faculty of Business, Princess Sumaya University for Technology, Amman, Jordan \\ ${ }^{2}$ Faculty of Business Administration, Mutah University, Karak, Jordan \\ Correspondence: Mohammed Issa Shahateet, Princess Sumaya University for Technology, King Talal Faculty of \\ Business, Amman 11941, Jordan. Tel: 962-777-804-848. E-mail: msh@psut.edu.jo
}

Received: July 3, 2014

doi:10.5539/ijef.v6n10p270

\author{
Accepted: July 24, 2014 \\ Online Published: September 25, 2014 \\ URL: http://dx.doi.org/10.5539/ijef.v6n10p270
}

\begin{abstract}
This paper aims at determining the relationship between economic growth and energy consumption in Jordan within the neo-classical productivity theory framework where capital, labour and energy are treated as separate production factors. It constructs an econometric model using annual time series data covering the period 19702011. After estimating the parameters of the model, it uses causality tests to examine the existence and direction of causality between output growth and production factors including energy consumption. Empirical findings suggest that there exists Granger causality running from GDP to energy consumption, but there is no Granger causality running from energy consumption to GDP. The implication being that energy supply constraints could be introduced with little or no impact on economic growth. This unidirectional causality provides empirical evidence that Jordan is a less energy-dependent economy. Such findings undermine the theory of energy conservation policies and support the Government policies that aim at raising the prices of energy and reducing public demand for energy consumption mainly to reduce the deficit of government budget, foreign debt, and its services.
\end{abstract}

Keywords: unit root, causality, cointegration, energy consumption, economic growth, Jordan

\section{Introduction}

Jordan is among the highest in the world in its dependency on foreign energy sources. During 2002-2012 more than $95 \%$ of the country's energy needs were imported. The meagre resource of energy along with the lack of prospects of oil makes Jordan extremely vulnerable to exogenous energy supply shocks. Furthermore, steadily rising energy demand for expensive crude oil have made it necessary for Jordan to follow a policy of energy conservation to reduce government debt by reducing energy subsidies and direct more inputs to boost economic growth.

Electricity consumption has been growing at a higher pace compared to economic growth due to increasing urbanization, industrialisation, and rural electrification. High prices of oil and the capacity in electric generation with low operating costs have also led to high electricity usage level. From 1970 to 1974, the electricity consumption increased by $15.5 \%$ annually. This pattern continued even at higher rates during the 80 's and 90 's. Figures that are more recent reveal that during 2001-2011 the average annual growth in electricity consumption was almost $7 \%$. In addition, the per capita energy consumption has also followed an overall upward trend, Central Bank of Jordan (2012). More recent years, 2010-2012, had experienced the most difficult times for the energy and electricity sector in Jordan due to the political conditions in the region which in turn contributed to increasing challenges facing this sector since Jordan imports more than $97 \%$ of its oil needs and that about $80 \%$ of electric power generated in Jordan depends on imported natural gas. In spite of these challenges, energy sector in Jordan has been able to continue its achievements and keep pace with recent and rapid developments by meeting the growing demand for different energy sources in general and electric power in particular. However, it has become urgent to find the appropriate solutions to face this fact in the light of the comprehensive national strategy of energy sector and the future vision derived from it which includes the need to utilize local energy sources depending on oil shale, uranium, use nuclear energy instead of oil to generate electric power, increase renewable energy sources projects, reinforce regional interconnection projects, and create opportunities for the private sector to invest in infrastructure projects of energy sector. This strategy seeks 
to increase reliance on local and renewable energy from $4 \%$ in the current year to $13 \%$ in 2016 , then to $39 \%$ in 2020, National Electric Power Company (2012, pp. 11-17). The paper contributes to the existing literature because the analysis focuses on a small developing country, Jordan, which has not been studied, from this angle, before.

\section{Review of Literature}

Many studies have addressed the relationship between energy consumption and economic growth for several countries using different models. The results of these studies reached fairly inconclusive, and sometimes controversial, results concerning the exact nature and direction of the relationship between energy and economic growth. The main differences identified were type of analysis, time span, the time periods examined, the econometric approaches and the variables included in the estimations, level of economic growth in different countries, and method of estimation. Another potential reason for the differences in the results of these studies is the degree of availability of data specific for the country, Inglesi-Lotz and Pouris (2013). This gives rise for further research to guide economic theories and plans to generate economic development. The major part of empirical research that was devoted to test causality and relationship between energy consumption and economic growth could be divided into four categories, hence assuming four hypotheses, Chang and Carballo (2011).

\subsection{Neutrality Hypothesis}

This hypothesis assumes no causality between energy consumption and economic growth. Its implication is that energy conservation will not lead to economic growth and economic growth is independent from energy use. The neutrality hypothesis is supported by many recent studies including Stern and Enflo (2013), Ozturk and Acaravci (2011), Ozturk and Acaravci (2010), Warr and Ayres (2010), Apergis and Payne (2009c), Halicioglu (2009), Soytas and Sari (2009), Chiou-Wei, Chen and Zhu (2008), Jobert and Karanfil (2007), Lee (2006), Soytas and Sari (2006a), Fata, Oxley and Scrimgeour (2004) and Soytas and Sari (2003).

\subsection{Conservation Hypothesis}

This hypothesis postulates that a one-way directional causality runs from GDP to energy consumption. This implies that energy conservation policies may be implemented with little or no adverse effects on economic growth. However, it is possible that a growing economy constrained by political, infrastructural, or mismanagement of resources could generate inefficiencies and the reduction in the demand for goods and services, including energy consumption. The running causality from GDP to energy consumption was demonstrated by Baranzini et al. (2013), Damette and Seghir (2013), Ouedraogo (2013), Azlina (2012), Haghnejad and Dehnavi (2012), Adom (2011), Abbasian, Nazary and Nasrindoost (2010), Jamil and Ahmad (2010), Khan and Qayyum (2009), Mehrara (2007), Mozumder and Marathe (2007), Al-Iriani (2006), Tehranchian (2006), Yoo (2006), Hatemi-J and Irandoust (2005), Narayan and Smyth (2005), Jumbe (2004) and Oh and Lee (2004b).

\subsection{Growth Hypothesis}

This hypothesis supports a uni-directional causality running from energy consumption to economic growth. The implication is that restrictions on the use of energy may adversely affect economic growth while increases in energy consumption may contribute to economic growth. This hypothesis is demonstrated by Damette and Seghir (2013), Javid, Javid and Awan (2013), Ouedraogo (2013), Solarin and Shahbaz (2013), Acaravci and Ozturk (2012), Haghnejad and Dehnavi (2012), Shahiduzzaman and Alam (2012), Kouakou (2011), Mazbahul and Nazrul (2011), Chandran et al. (2010), Chang (2010), Odhiambo (2010), Yoo and Kwak (2010), Apergis and Payne (2009b), Akinlo (2009), Bowden and Payne (2009), Odhiambo (2009a, 2009b), Erdal, Erdal and Esengun (2008), Lee and Chang (2008), Narayan and Smyth (2008), Ang (2007), Ho and Siu (2007), Mahadevan and Asafu-Adjaye (2007), Yuan et al. (2007), Zhou and Chau (2006), Lee (2005), Lee and Chang (2005), Yoo (2005), Fatai Oxley and Scrimgeour (2004), Ghali and El-Sakka (2004), Morimoto and Hope (2004), Paul and Bhattacharya (2004), Shiu and Lam (2004), Wolde-Rufael (2004) and Soytas and Sari (2003).

\subsection{Feedback Hypothesis}

Feedback hypothesis assumes a bi-directional causality between energy consumption and economic growth. It implies that any energy conservation policy will adversely affect the economic output, while an increase in the economic output will increase the level of energy consumption. This hypothesis of causal relation between energy consumption and economic growth was demonstrated by many authors including Belaid and Abderrahmani (2013), Hu and Lin (2013), Tang and Tan (2013), Shahbaz and Lean (2012), Zhang and Yang (2012), Kouakou (2011), Ouédraogo (2010), Apergis and Payne (2009a), Belloumi (2009), Erdal, Erdal and Esengun (2008), Lee et al. (2008), Chen, Kou and Chen (2007), Lee and Chang (2007), Mahadevan and 
Asafu-Adjaye (2007), Squalli (2007), Zhang and Li (2007), Soytas and Sari (2006b), Yoo (2006), Zhou and Chau (2006), Fatai, Oxley and Scrimgeour (2004), Ghali and El-Sakka (2004), Jumbe (2004), Oh and Lee (2004a) and Paul and Battacharya (2004).

\section{Methodology and Data}

The analysis depends on investigating the causal relationship among energy consumption, labour, capital, and economic growth, by using Jordanian annual time series data for the period 1970-2011. Before conducting the cointegration analysis, we conduct a unit root test for the variables of the model. We adopt two different tests, namely those of Augmented Dicky-Fuller (ADF) and Phillips-Perron (PP). For specifying the cointegrating of the equations of the model, we applied Johansen's cointegration test in two forms: linear deterministic trend and no deterministic trend. Finally, to determine the existence and direction of causality among the variables of the model we applied Granger causality test with constant term and no trend.

\section{The Model}

Following Ghali and El-Sakka (2004), Oh and Lee (2004a) and many others, we start with a modified form of the aggregate output function as follows

$$
Y_{t}=f\left(K_{t}, L_{t}, E_{t}\right)
$$

Where $Y$ is the aggregate output, $K$ is capital, $L$ is labour, and $E$ is energy consumption. Maintaining linearity and following the neo-classical productivity theory, we basically depend on a modified form of production function as follows

$$
G D P_{t}=\alpha_{0}+\alpha_{1} K_{t}+\alpha_{2} L_{t}+\alpha_{3} E_{t}+\varepsilon_{t}
$$

The choice of a model which is based on the neo-classical productivity theory is meant to enrich the analysis of the relationship among the aggregate output and its factors of input, considering not only the energy variable but also capital and labor. As noted by Ghali and El-Sakka (2004), whether proposition of neutrality of energy in income determination is true or not, it is best to be tested in a neo-classical aggregated production framework taking capital, labor, and energy as separate inputs. Accordingly, we propose the following model:

$$
\begin{gathered}
\Delta G D P_{t}=\alpha_{0}+\sum_{i=1}^{n} \alpha_{1 i} \Delta G D P_{t-i}+\sum_{i=0}^{n} \alpha_{2 i} \Delta K_{t-i}+\sum_{i=0}^{n} \alpha_{3 i} \Delta L_{t-i}+\sum_{i=0}^{n} \alpha_{4 i} \Delta E_{t-i}+u_{1} \\
\Delta K_{t}=\beta_{0}+\sum_{i=1}^{n} \beta_{1 i} \Delta K_{t-i}+\sum_{i=0}^{n} \beta_{2 i} \Delta G D P_{t-i}+\sum_{i=0}^{n} \beta_{3 i} \Delta L_{t-i}+\sum_{i=0}^{n} \beta_{4 i} \Delta E_{t-i}+u_{2} \\
\Delta L_{t}=\gamma_{0}+\sum_{i=1}^{n} \gamma_{1 i} \Delta L_{t-i}+\sum_{i=0}^{n} \gamma_{2 i} \Delta G D P_{t-i}+\sum_{i=0}^{n} \gamma_{3 i} \Delta K_{t-i}+\sum_{i=0}^{n} \gamma_{4 i} \Delta E_{t-i}+u_{3} \\
\Delta E_{t}=\delta_{0}+\sum_{i=1}^{n} \delta_{1 i} \Delta E_{t-i}+\sum_{i=0}^{n} \delta_{2 i} \Delta G D P_{t-i}+\sum_{i=0}^{n} \delta_{3 i} \Delta K_{t-i}+\sum_{i=0}^{n} \delta_{4 i} \Delta L_{t-i}+u_{4}
\end{gathered}
$$

For testing cointergration with linear deterministic trends, the above model can simply be written as:

$$
\begin{gathered}
\Delta G D P_{t}=\alpha_{0}+\sum_{i=1}^{n} \alpha_{1 i} \Delta G D P_{t-i}+\sum_{i=0}^{n} \alpha_{2 i} \Delta K_{t-i}+\sum_{i=0}^{n} \alpha_{3 i} \Delta L_{t-i}+\sum_{i=0}^{n} \alpha_{4 i} \Delta E_{t-i}+\alpha_{5} t+u_{1} \\
\Delta K_{t}=\beta_{0}+\sum_{i=1}^{n} \beta_{1 i} \Delta K_{t-i}+\sum_{i=0}^{n} \beta_{2 i} \Delta G D P_{t-i}+\sum_{i=0}^{n} \beta_{3 i} \Delta L_{t-i}+\sum_{i=0}^{n} \beta_{4 i} \Delta E_{t-i}+\beta_{5} t+u_{2} \\
\Delta L_{t}=\gamma_{0}+\sum_{i=1}^{n} \gamma_{1 i} \Delta L_{t-i}+\sum_{i=0}^{n} \gamma_{2 i} \Delta G D P_{t-i}+\sum_{i=0}^{n} \gamma_{3 i} \Delta K_{t-i}+\sum_{i=0}^{n} \gamma_{4 i} \Delta E_{t-i}+\gamma_{5} t+u_{3} \\
\Delta E_{t}=\delta_{0}+\sum_{i=1}^{n} \delta_{1 i} \Delta E_{t-i}+\sum_{i=0}^{n} \delta_{2 i} \Delta G D P_{t-i}+\sum_{i=0}^{n} \delta_{3 i} \Delta K_{t-i}+\sum_{i=0}^{n} \delta_{4 i} \Delta L_{t-i}+\delta_{5} t+u_{4}
\end{gathered}
$$

For simplicity, $n$ represents the maximum number of lags which is not necessarily fixed for each variable but determined by the estimation method (Least Squares) based on Schwarz Information Criterion (SIC). Small Greek letters $(\alpha, \beta, \gamma$ and $\delta)$ are coefficients to be estimated, and $u$ 's are stochastic errors.

\section{Empirical Results and Discussion}

Empirical findings regarding the direction of causality have significant policy implications. If the findings confirm that causality runs one-way from energy to economic growth then this implies that the economy, under study, is an energy-dependent economy. Moreover, energy is a stimulus for economic growth, implying that energy conservation plans may slow down economic growth. On the other hand, a unidirectional causality running from economy to energy consumption provides empirical evidence that the economy, under study, is a less energy-dependent economy. Such findings undermine the theory of energy conservation policies. More precisely, energy rationing may be implemented with little or no impact on economic growth. If there is no causality between energy consumption and economic growth, which is a rare and, probably, an old case, then a country can carry out energy conservation policies with no or little effect on economic growth. For such policies to work in the Jordanian case, this study provides empirical evidence through several tests including unit root test, cointegration and causality test. 


\subsection{Unit Root Test}

In order to have robust results, we conducted two different unit root tests, namely Augmented Dickey-Fuller (ADF) and Phillips-Perron (PP). The results of unit root tests or stationarity properties of all model variables along with the number of lag lengths are presented in Table 1. The unit root tests for both level and first difference forms are performed including a constant without linear trend. A linear trend needs only be included if the variables in level have a second trend. This is not the case for our variables. The null hypothesis that a variable has a unit root is rejected for values of t-statistics greater than or equal to their corresponding critical (or tabled) t-values.

As can be seen, only the t statistics for GDP are greater than their corresponding critical values at the 5\% level from both $\mathrm{ADF}$ and PP tests, suggesting that the variables $K, L$, and $E$ are nonstationary in their level forms implying the need for stationarity testing for the variables in their first differences. The results of the first differenced variables $K, L$, and $E$ show that $\mathrm{ADF}$ and PP test statistics for all the variables are less than their critical values at $5 \%$ levels, notice negative values of $t$ or adjusted $t$ statistics. The results show that all the variables are stationary after differencing once, suggesting that all the variables are integrated of order I(1) except for GDP which is stationary at its level which is integrated of order I $(0)$. The two tests almost unanimously indicate that all the variables are non-stationary in their level data except for GDP (with or without trend). However, the stationarity property is found in the first difference of the variables (with constant and without trend) at the $5 \%$ level.

Table 1. Empirical results of unit root test

\begin{tabular}{lllll}
\hline Level form & $G D P$ & $K$ & $L$ & $E$ \\
\hline Augmented Dicky-Fuller test statistic & $8.499(0)$ & $3.461(9)$ & $0.635(1)$ & $-0.449(0)$ \\
Phillips-Perron test statistic & $8.224(1)$ & $1.353(3)$ & $1.326(3)$ & $-0.467(2)$ \\
Significance level & Critical values & Critical values & Critical values & Critical values \\
$1 \%$ & -3.601 & -3.654 & -3.605 & -3.601 \\
$5 \%$ & -2.935 & -2.957 & -2.937 & -2.935 \\
$10 \%$ & -2.606 & -2.617 & -2.607 & -2.606 \\
\hline First difference & $G D P$ & $K$ & $L$ & $E$ \\
\hline Augmented Dicky-Fuller test statistic & $-0.466(1)$ & $-4.457(0)$ & $-3.549(0)$ & $-5.941(0)$ \\
Phillips-Perron test statistic & $-2.059(3)$ & $-4.562(4)$ & $-3.519(2)$ & $-5.947(2)$ \\
Significance level & Critical values & Critical values & Critical values & Critical values \\
$1 \%$ & -3.610 & -3.606 & -3.606 & -3.601 \\
$5 \%$ & -2.939 & -2.937 & -2.937 & -2.935 \\
$10 \%$ & -2.608 & -2.607 & -2.607 & -2.606 \\
\hline
\end{tabular}

Note. $G D P$ and $K$ are in real terms. For Augmented Dicky-Fuller test statistics, the numbers in parentheses are lag length which is selected automatically based on assumed maximum lag length of 9 . For Phillips-Perron test statistics, the numbers in parentheses are bandwidths (Newey-West automatic) using Bartlett kernel.

\subsection{Co-Integration}

Cointegration analysis has been carried out to investigate the long-run cointegration among the variables of the model. In this study, we applied unit root tests to the residuals obtained from OLS estimation. To establish if the variables are cointegrated, the ADF unit roots test was applied on the residuals from the three equations, where $E$ was regressed on each of the variables $G D P, K$ and $L$. Table 2, Table 3, Table 4 and Table 5 present the results from this analysis. When testing for cointegration among the variables using Trace tests with no linear deterministic trend, shown in Tables 2 and 3, we arrive at the conclusion that there is one cointegrating equation using Trace test and two cointegrating equations using Maximum Eigenvalue method, as assumed in equations (2a), (3a), (4a), and (5a). 
Table 2. Results for unrestricted cointegration rank test (trace) with no deterministic trend

\begin{tabular}{ccccc}
\hline $\begin{array}{c}\text { Hypothesized } \\
\text { No. of CE(s) }\end{array}$ & Eigenvalue & $\begin{array}{c}\text { Trace } \\
\text { Statistic }\end{array}$ & $\begin{array}{c}0.05 \\
\text { Critical Value }\end{array}$ & Prob.** \\
\hline None ${ }^{*}$ & 0.738173 & 77.85327 & 40.17493 & 0.0000 \\
At most 1 & 0.380375 & 24.25045 & 24.27596 & 0.0504 \\
At most 2 & 0.089771 & 5.104784 & 12.32090 & 0.5530 \\
At most 3 & 0.033004 & 1.342432 & 4.129906 & 0.2884 \\
\hline
\end{tabular}

Note. Trace test indicates 1 cointegrating eqn(s) at the 0.05 level, * denotes rejection of the hypothesis at the 0.05 level. **MacKinnon-Haug-Michelis (1999) p-values.

Table 3. Results for Unrestricted Cointegration Rank Test (Maximum Eigenvalue) with no deterministic trend

\begin{tabular}{ccccc}
\hline $\begin{array}{c}\text { Hypothesized } \\
\text { No. of CE(s) }\end{array}$ & Eigenvalue & $\begin{array}{c}\text { Max-Eigen } \\
\text { Statistic }\end{array}$ & $\begin{array}{c}0.05 \\
\text { Critical Value }\end{array}$ & Prob.** \\
\hline None $*$ & 0.738173 & 53.60283 & 24.15921 & 0.0000 \\
At most 1 & 0.380375 & 19.14566 & 17.79730 & 0.0312 \\
At most 2 & 0.089771 & 3.762351 & 11.22480 & 0.6665 \\
At most 3 & 0.033004 & 1.342432 & 4.129906 & 0.2884 \\
\hline
\end{tabular}

Note. Max-eigenvalue test indicates 2 cointegrating eqn(s) at the 0.05 level; * denotes rejection of the hypothesis at the 0.05 level; **MacKinnon-Haug-Michelis (1999) p-values

As can be seen, the null hypothesis of no cointegrating equations is rejected at the $5 \%$ level of significance, as assumed in equations (2b), (3b), (4b), and (5b). The results of both rank tests (Trace and Maximum Eigenvalue) with linear deterministic trend, shown in Tables 4 and 5, indicate that there is one cointegrating equation at the 5\% level.

Table 4. Results for unrestricted cointegration rank test (trace) tests with linear deterministic trend

\begin{tabular}{ccccc}
\hline $\begin{array}{c}\text { Hypothesized } \\
\text { No. of CE(s) }\end{array}$ & Eigenvalue & $\begin{array}{c}\text { Trace } \\
\text { Statistic }\end{array}$ & $\begin{array}{c}0.05 \\
\text { Critical Value }\end{array}$ & Prob.** \\
\hline None $*$ & 0.743981 & 80.20033 & 47.85613 & 0.0000 \\
At most 1 & 0.347355 & 25.70012 & 29.79707 & 0.1379 \\
At most 2 & 0.186548 & 8.631218 & 15.49471 & 0.4006 \\
At most 3 & 0.009269 & 0.372508 & 3.841466 & 0.5416 \\
\hline
\end{tabular}

Note. Trace test indicates 1 cointegrating eqn(s) at the 0.05 level; * denotes rejection of the hypothesis at the 0.05 level; **MacKinnon-Haug-Michelis (1999) p-values.

Table 5. Results for Unrestricted Cointegration Rank Test (Maximum Eigenvalue) with linear deterministic trend

\begin{tabular}{ccccc}
\hline $\begin{array}{c}\text { Hypothesized } \\
\text { No. of CE(s) }\end{array}$ & Eigenvalue & $\begin{array}{c}\text { Max-Eigen } \\
\text { Statistic }\end{array}$ & $\begin{array}{c}0.05 \\
\text { Critical Value }\end{array}$ & Prob.** \\
\hline None ${ }^{*}$ & 0.743981 & 54.50022 & 27.58434 & 0.0000 \\
At most 1 & 0.347355 & 17.06890 & 21.13162 & 0.1688 \\
At most 2 & 0.186548 & 8.258710 & 14.26460 & 0.3530 \\
At most 3 & 0.009269 & 0.372508 & 3.841466 & 0.5416 \\
\hline
\end{tabular}

Note. Max-eigenvalue test indicates 1 cointegrating eqn(s) at the 0.05 level. * denotes rejection of the hypothesis at the 0.05 level; **MacKinnon-Haug-Michelis (1999) p-values.

\subsection{Causality Test}

The empirical results fully support the existence of a unidirectional causality running from economic growth to energy consumption. This means that reducing energy consumption does not adversely affect GDP. Moreover, neoclassical theory of production is fully supported by Jordanian data as both capital and labor causes economic growth. As can be seen from Table 6 , there is only a probability of less than $2 \%(1.61 \%)$ to reject the null hypothesis that capital does not cause GDP growth. On the other hand, we are $96 \%$ confident that labor causes 
output growth. More important to this paper is that energy consumption has no significant effect on economic growth.

Table 6. Pair wise granger causality tests

\begin{tabular}{lccll}
\hline Null Hypothesis: & No. of Observations & F-Statistic & Probability & Result \\
\hline$K$ does not Granger Cause $G D P$ & 40 & 4.65712 & 0.0161 & Reject \\
$G D P$ does not Granger Cause $K$ & & 1.32356 & 0.2792 & Do not reject \\
$L$ does not Granger Cause GDP & 40 & 3.53815 & 0.0399 & Reject \\
$G D P$ does not Granger Cause $L$ & & 1.25031 & 0.2989 & Do not reject \\
$E$ does not Granger Cause $G D P$ & 40 & 1.98693 & 0.1523 & Do not reject \\
$G D P$ does not Granger Cause $E$ & & 3.64440 & 0.0365 & Reject \\
$L$ does not Granger Cause $K$ & 40 & 8.44389 & 0.0010 & Reject \\
$K$ does not Granger Cause $L$ & & 0.09062 & 0.9136 & Do not reject \\
$E$ does not Granger Cause $K$ & 40 & 3.16164 & 0.0547 & Do not reject \\
$K$ does not Granger Cause $E$ & & 5.78664 & 0.0067 & Reject \\
$E$ does not Granger Cause $L$ & 40 & 3.09734 & 0.0577 & Reject \\
$L$ does not Granger Cause $E$ & & 0.89413 & 0.4181 & Do not reject \\
\hline
\end{tabular}

Note. GDP is real gross domestic product (million JD), $L$ is labour, $K$ is capital expressed in real gross capital formation (million JD), and $E$ is energy consumption expressed in electricity consumption $(\mathrm{kWh})$.

\section{Conclusions}

This paper provides new empirical insight into the analysis of the relationship between energy consumption and economic growth for a small developing country considering the traditional factors of production in addition to energy factor. In this context, modeling energy consumption and economic growth in Jordan during 1971-2011 has enabled us to test energy consumption and economic growth relationship in a neo-classical aggregate production model. The empirical findings indicate that there exists long-run cointegration among output, labor, capital and energy use. Granger causality tests indicate that there exists Granger causality running from GDP to energy consumption, but Granger causality running from energy consumption to GDP does not exist. It can also be concluded that conservation hypothesis is applicable to Jordanian data more than the feedback or growth hypotheses.

An important policy implication of the analysis is that conservation in energy consumption is not a significant limiting factor to Jordanian economic growth. Therefore, energy supply constraints could be introduced with little impact on economic growth. This unidirectional causality provides empirical evidence that energy conservation policies are favourable for Jordanian economy. They also support the Government policies that aim at reducing public demand for energy consumption mainly to minimise foreign debt and its services. This should not be interpreted as energy has nothing to do with economic growth but rather there are other factors, such as labour and capital, which are more important to economic growth than energy consumption.

\section{References}

Abbasian, E., Nazari, M., Nasrindoost, M. (2010). Energy consumption and economic growth in the Iranian economy: Testing the causality relationship. Middle-East Journal of Scientific Research, 5, 374-381.

Acaravci, A., \& Ozturk, I. (2012). Electricity consumption and economic growth nexus: A multivariate analysis for Turkey. Amfiteatru Economic, 14, 246-257.

Adom, P. K. (2011). Electricity consumption-economic growth nexus: The Ghanaian case. International Journal of Energy Economics and Policy, 1, 18-31.

Akinlo, A. E. (2009). Electricity consumption and economic growth in Nigeria: Evidence from cointegration and co-feature analysis. Journal of Policy Modeling, 31, 681-693. http://dx.doi.org/10.1016/j.jpolmod.2009.03.004

Al-Iriani, M. A. (2006). Energy-GDP relationship revisited: An example from GCC countries using panel causality. Energy Policy, 34, 3342-3350. http://dx.doi.org/10.1016/j.enpol.2005.07.005

Ang, J. B. (2007). CO2 emissions, energy consumption, and output in France. Energy Policy, 35, 4772-4778. http://dx.doi.org/10.1016/j.enpol.2007.03.032 
Apergis, N., \& Payne, J. (2009a). CO2 emissions, energy usage, and output in Central America. Energy Policy, 37, 3282-3286. http://dx.doi.org/10.1016/j.enpol.2009.03.048

Apergis, N., \& Payne, J. (2009b). Energy consumption and economic growth in Central America: Evidence from a panel cointegration and error correction model. Energy Economics, 31, 211-216. http://dx.doi.org/10.1016/j.eneco.2008.09.002

Apergis, N., \& Payne, J. (2009c). Energy consumption and economic growth: Evidence from the Common wealth of Independent States. Energy Economics, 31, 641-647. http://dx.doi.org/10.1016/j.eneco.2009.01.011

Azlina, A. A. (2012). Energy consumption and economic development in Malaysia: A multivariate cointegration analysis. Procedia-Social and Behavioral Sciences, 674-681. http://dx.doi.org/10.1016/j.sbspro.2012.11.183

Baranzini, A., Weber, S., Bareit, M., \& Mathys, N. A. (2013). The causal relationship between energy use and economic growth in Switzerland. Energy Economics, 36, 464-470. http://dx.doi.org/10.1016/j.eneco.2012.09.015

Bélaïd, F., \& Abderrahmani, F. (2013). Electricity consumption and economic growth in Algeria: A multivariate causality analysis in the presence of structural change. Energy Policy, 55, 286-295. http://dx.doi.org/10.1016/j.enpol.2012.12.004

Belloumi, M. (2009). Energy consumption and GDP in Tunisia: Cointegration and causality analysis. Energy Policy, 37, 2745-2753. http://dx.doi.org/10.1016/j.enpol.2009.03.027

Bowden, N., \& Payne, J. (2009). The causal relationship between U.S. energy consumption and real output: A disaggregated analysis. Journal of Policy Modeling, 31, 180-188. http://dx.doi.org/10.1016/j.jpolmod.2008.09.001

Central Bank of Jordan. (2012). Annual Report, No. 49, Central Bank of Jordan, Amman.

Chandran, V. G. R., Sharma, S., \& Madhavan, K. (2010). Electricity consumption-growth nexus: The case of Malaysia. Energy Policy, 38, 606-612. http://dx.doi.org/10.1016/j.enpol.2009.10.013

Chang, C. C. (2010). A multivariate causality test of carbon dioxide emissions, energy consumption and economic growth in China. Applied Energy, 87, 3533-3537. http://dx.doi.org/10.1016/j.apenergy.2010.05.004

Chang, C. C., \& Soruco, C. C. F. (2011). Energy conservation and sustainable economic growth: The case of Latin America and the Caribbean. Energy Policy, 39, 4215-4221. http://dx.doi.org/10.1016/j.enpol.2011.04.035

Chen, S. T., Kou, H. I., \& Chen, C. C. (2007). The relationship between GDP and electricity consumption in 10 Asian Countries. Energy Policy, 35, 2611-2621. http://dx.doi.org/10.1016/j.enpol.2006.10.001

Chiou-Wei, S. Z., Chin, C., \& Zhu, Z. (2008). Economic growth and energy consumption revisited-evidence from linear and nonlinear granger causality. Energy Economics, 30, 3063-3076. http://dx.doi.org/10.1016/j.eneco.2008.02.002

Damette, O., \& Seghir, M. (2013). Energy as a driver of growth in oil exporting countries? Energy Economics, 37, 193-199. http://dx.doi.org/10.1016/j.eneco.2012.12.011

Erdal, G., Erdal, H., \& Esengun, K. (2008). The causality between energy consumption and economic growth in Turkey. Energy Policy, 36(10), 3838-3842. http://dx.doi.org/10.1016/j.enpol.2008.07.012

Fatai, K., Oxley, L., \& Scrimgeour, F. G. (2004). Modelling the causal relationship between energy consumption and GDP in New Zealand, Australia, India, Indonesia, the Phillippines and Thailand. Mathematics and Computers in Simulation, 64, 431-445. http://dx.doi.org/10.1016/S0378-4754(03)00109-5

Ghali, K. H., \& El-Sakka, M. I. T. (2004). Energy consumption and output growth in Canada: A multivariate cointegration analysis. Energy Economics, 26, 225-238. http://dx.doi.org/10.1016/S0140-9883(03)00056-2

Haghnejad, A., \& Dehnavi, J. (2012). Energy consumption, economic growth, and pollution in selected OPEC countries: Testing the environmental Kuznets curve hypothesis. Journal of Academic Research in Economics, 2, 149-166.

Halicioglu, F. (2009). An econometric study of CO2 emissions, energy consumption, income and foreign trade in Turkey. Energy Policy, 37, 1156-1164. http://dx.doi.org/10.1016/j.enpol.2008.11.012 
Hatemi-J, A., \& Irandoust, M. (2005). Energy consumption and economic growth in Sweden: A leveraged bootstrap approach (1965-2000). International Journal of Applied Econometrics and Quantitative Studies, 2, 87-98.

Ho, C., \& Siu, K. W. (2007). A dynamic equilibrium of electricity consumption and GDP in Hong Kong: An empirical investigation. Energy Policy, 35, 2507-2513. http://dx.doi.org/10.1016/j.enpol.2006.09.018

Hu, X., \& Lin, X. (2013). A study of the relationship between electricity consumption and GDP growth in Hainan international tourism island of China. Research in World Economy, 4, 109-115. http://dx.doi.org/10.5430/rwe.v4n1p109

Inglesi-Lotz, R., \& Pouris, A. (2013). On the causality and determinants of energy and electricity demand in South Africa: A review. Department of Economics Working Paper Series, University of Pretoria, Working Paper: 2013-14.

Jamil, F., \& Ahmad, E. (2010). The relationship between electricity consumption, electricity prices and GDP in Pakistan. Energy Policy, 38, 6016-6025. http://dx.doi.org/10.1016/j.enpol.2010.05.057

Javid, A. Y, Javid, M., \& Awan, Z. A. (2013). Electricity consumption and economic growth: Evidence from Pakistan. Economics and Business Letters, 2, 21-32.

Jobert, T., \& Karanfil, F. (2007). Sectoral energy consumption by source and economic growth in Turkey. Energy Policy, 35, 5447-5456. http://dx.doi.org/10.1016/j.enpol.2007.05.008

Jumbe, C. B. L. (2004). Cointegration and causality between electricity consumption and GDP: Empirical evidence from Malawi. Energy Economics, 26, 61-68. http://dx.doi.org/10.1016/S0140-9883(03)00058-6

Khan, M. A., \& Qayyum, A. (2009). The demand for electricity in Pakistan. OPEC Energy Review, March, 7096. http://dx.doi.org/10.1111/j.1753-0237.2009.00158.x

Kouakou, A. K. (2011). Economic growth and electricity consumption in Cote d'Ivoire: Evidence from time series analysis. Energy Policy, 39, 3638-3644. http://dx.doi.org/10.1016/j.enpol.2011.03.069

Lee, C., \& Chang, C. (2007). Energy consumption and GDP revisited: A panel analysis of developed and developing countries. Energy Economics, 29, 1206-1223. http://dx.doi.org/10.1016/j.eneco.2007.01.001

Lee, C., Chang, C., \& Chen, P. (2008). Energy-income causality in OECD countries revisited: The key role of capital stock. Energy Economics, 30, 2359-2373. http://dx.doi.org/10.1016/j.eneco.2008.01.005

Lee, C. C. (2005). Energy consumption and GDP in developing countries: A cointegrated panel analysis. Energy Economics, 27, 415-427. http://dx.doi.org/10.1016/j.eneco.2005.03.003

Lee, C. C. (2006). The causality relationship between energy consumption and GDP in G-11 countries revisited. Energy Policy, 34, 1086-1093. http://dx.doi.org/10.1016/j.enpol.2005.04.023

Lee, C. C., \& Chang, C. P. (2005). Structural breaks, energy consumption, and economic growth revisited: Evidence from Taiwan. Energy Economics, 27, 857-872. http://dx.doi.org/10.1016/j.eneco.2005.08.003

Lee, C. C., \& Chang, C. P. (2008). Energy consumption and economic growth in Asian economies: A more comprehensive analysis using panel data. Resource and Energy Economics, 30, 50-65. http://dx.doi.org/10.1016/j.reseneeco.2007.03.003

MacKinnon, J. G., Haug, A. A., \& Michelis, L. (1999). Numerical distribution functions of likelihood ratio tests for cointegration. Journal of Applied Econometrics, 14, 563-577. http://dx.doi.org/10.1002/(SICI)1099-1255(199909/10)14:5<563::AID-JAE530>3.0.CO;2-R

Mahadevan, R., \& Asafu-Adjaye, J. (2007). Energy consumption, economic growth and prices: A reassessment using panel VECM for developed and developing countries. Energy Policy, 35, 2481-2490. http://dx.doi.org/10.1016/j.enpol.2006.08.019

Mazbahul, G. A., \& Nazrul, A. K. M. (2011). Electricity consumption and economic growth nexus in Bangladesh: Revisited evidences. Energy Policy, 39, 6145-6150. http://dx.doi.org/10.1016/j.enpol.2011.07.014

Mehrara, M. (2007). Energy Consumption and Economic Growth: The Case of Oil Exporting Countries. Energy Policy, 35, 2939-2945. http://dx.doi.org/10.1016/j.enpol.2006.10.018

Morimoto, R., \& Hope, C. (2004). The impact of electricity supply on economic growth in Sri Lanka. Energy Economics, 26, 77-85. http://dx.doi.org/10.1016/S0140-9883(03)00034-3

Mozumder, P., \& Marathe, A. (2007). Causality relationship between electricity consumption and GDP in 
Bangladesh. Energy Policy, 35, 395-402. http://dx.doi.org/10.1016/j.enpol.2005.11.033

Narayan, P. K., \& Smyth, R. (2005). Electricity consumption, employment and real income in Australia: Evidence from multivariate Granger causality tests. Energy Policy, 33, 1109-1116. http://dx.doi.org/10.1016/j.enpol.2003.11.010

Narayan, P. K., \& Smyth, R. (2008). Energy consumption and real GDP in G7 countries: New evidence from panel cointegration with structural breaks. Energy Economics, 30, 2331-2341. http://dx.doi.org/10.1016/j.eneco.2007.10.006

National Electric Power Company. (2012). Annual Report 2011, National Electric Power Company, Amman.

Odhiambo, N. (2009a). Energy consumption and economic growth nexus in Tanzania: An ARDL bounds testing approach. Energy Policy, 37, 617- 622. http://dx.doi.org/10.1016/j.enpol.2008.09.077

Odhiambo, N. (2009b). Electricity consumption and economic growth in South Africa: A trivariate causality test. Energy Economics, 31, 635-640. http://dx.doi.org/10.1016/j.eneco.2009.01.005

Odhiambo, N. (2010). Energy consumption, prices and economic growth in three SSA countries: A comparative study. Energy Policy, 38, 2463-2469. http://dx.doi.org/10.1016/j.enpol.2009.12.040

Oh, W., \& Lee, K. (2004a). Causal relationship between energy consumption and GDP revisited: The case of Korea 1970-1999. Energy Economics, 26, 51-59. http://dx.doi.org/10.1016/S0140-9883(03)00030-6

Oh, W., \& Lee, K. (2004b). Energy consumption and economic growth in Korea: Testing the causality relation. Journal of Policy Modeling, 26, 973-981. http://dx.doi.org/10.1016/j.jpolmod.2004.06.003

Ouédraogo, I. (2010). Electricity consumption and economic growth in Burkina Faso: A cointegration analysis. Energy Economics, 32, 524-531. http://dx.doi.org/10.1016/j.eneco.2009.08.011

Ouedraogo, N. S. (2013). Energy consumption and economic growth: Evidence from the economic community of West African States (ECOWAS). Energy Economics, 36, 637-647. http://dx.doi.org/10.1016/j.eneco.2012.11.011

Ozturk, I., \& Acaravci, A. (2010). The Causal Relationship between Energy Consumption and GDP in Albania, Bulgaria, Hungary and Romania: Evidence from ARDL Bound Testing Approach. Applied Energy, 87, 1938-1943. http://dx.doi.org/10.1016/j.apenergy.(2009).10.010.

Ozturk, I., \& Acaravci, A. (2011). Electricity consumption and real GDP causality nexus: Evidence from ARDL bounds testing approach for 11 MENA countries. Applied Energy, 88, 2885-2892. http://dx.doi.org/10.1016/j.apenergy.2011.01.065

Paul, S., \& Bhattacharya, R. N. (2004). Causality between energy consumption and economic growth in India: A note on conflicting results. Energy Economics, 26, 977-983. http://dx.doi.org/10.1016/j.eneco.2004.07.002

Shahbaz, M., \& Lean, H. H. (2012). The dynamics of electricity consumption and economic growth: A revisit study of their causality in Pakistan. Energy, 39, 146-153. http://dx.doi.org/10.1016/j.energy.2012.01.048

Shahiduzzaman, M., \& Alam, K. (2012). Cointegration and causal relationships between energy consumption and output: Assessing the evidence from Australia. Energy Economics, 34, 2182-2188. http://dx.doi.org/10.1016/j.eneco.2012.03.006

Shiu, A., \& Lam, P. (2004). Electricity consumption and economic growth in China. Energy Policy, 32, 47-54. http://dx.doi.org/10.1016/S0301-4215(02)00250-1

Solarin, S. A., \& Shahbaz, M. (2013). Trivariate causality between economic growth, urbanisation and electricity consumption in Angola: Cointegration and causality analysis. MPRA Paper No. 45580. Retrieved from http://mpra.ub.uni-muenchen.de/45580/

Soytas, U., \& Sari, R. (2003). Energy consumption and GDP: Causality relationship in G7 countries and emerging markets. Energy Economics, 25, 33-37. http://dx.doi.org/10.1016/S0140-9883(02)00009-9

Soytas, U., \& Sari, R. (2006a). Can China contribute more to the fight against global warming? Journal of Policy Modelling, 28, 837-846. http://dx.doi.org/10.1016/j.jpolmod.2006.06.016

Soytas, U., \& Sari, R. (2006b). Energy consumption and income in G-7 countries. Journal of Policy Modelling, 28, 739-750. http://dx.doi.org/10.1016/j.jpolmod.2006.02.003

Soytas, U., \& Sari, R. (2009). Energy consumption, economic growth, and carbon emissions: Challenges faced by an EU candidate member. Ecological Economics, 68(6), 1667-1675. 
http://dx.doi.org/10.1016/j.ecolecon.2007.06.014

Squalli, J. (2007). Electricity consumption and economic growth: Bounds and causality analyses of OPEC Members. Energy Economics, 29, 1192-1205. http://dx.doi.org/10.1016/j.eneco.2006.10.001

Stern, D. I., \& Enflo, K. (2013). Causality between energy and output in the long-run. Lund Papers in Economic History, 126.

Tang, C. F., \& Tan, E. C. (2013). Exploring the nexus of electricity consumption, economic growth, energy prices and technology innovation in Malaysia. Applied Energy, 104, 297-305. http://dx.doi.org/10.1016/j.apenergy.2012.10.061

Tehranchian, A. (2006). On the relationship between energy consumption and real GDP in Iran: An application of VEC. Iranian Economic Review, 11, 353-367.

Warr, B. S., \& Ayres, R. U. (2010). Evidence of causality between the quantity and quality of energy consumption and economic growth. Energy, 35, 1688-1693. http://dx.doi.org/10.1016/j.energy.2009.12.017

Wolde-Rufael, Y. (2004). Disaggregated industrial energy consumption and GDP: The case of Shanghai, 19521999. Energy Economics, 26(1), 69-75. http://dx.doi.org/10.1016/S0140-9883(03)00032-X

Yoo, S. H. (2005). Electricity consumption and economic growth: Evidence from Korea. Energy Policy, 33, 1627-1632. http://dx.doi.org/10.1016/j.enpol.2004.02.002

Yoo, S. H. (2006). The causal relationship between electricity consumption and economic growth in the ASEAN countries. Energy Policy, 34(18), 3573-3582. http://dx.doi.org/10.1016/j.enpol.2005.07.011

Yoo, S. H., \& Kwak, S. Y. (2010). Electricity consumption and economic growth in seven South American countries. Energy Policy, 38, 181-188. http://dx.doi.org/10.1016/j.enpol.2009.09.003

Yuan, J., Zhao, C., Yu, S., \& Hu, Z. (2007). Electricity consumption and economic growth in China: Cointegration and co-feature analysis. Energy Economics, 29, 1179-1191. http://dx.doi.org/10.1016/j.eneco.2006.09.005

Zhang, W., \& Yang, S. (2012). The influence of energy consumption of China on its real GDP from aggregated and disaggregated viewpoints. Energy Policy, (in press).

Zhang, Y., \& Li, W. (2007). Study on causal relationship between coal consumption and economic growth in China. Resources \& Industries, 9(1), 89-93.

Zhou, G., \& Chau, K. W. (2006). Short and long-run effects between oil consumption and economic growth in China. Energy Policy, 34, 3644-3655. http://dx.doi.org/10.1016/j.enpol.2005.08.009

\section{Copyrights}

Copyright for this article is retained by the author(s), with first publication rights granted to the journal.

This is an open-access article distributed under the terms and conditions of the Creative Commons Attribution license (http://creativecommons.org/licenses/by/3.0/). 